УДК 343.98.001.36

DOI https://doi.org/10.32849/2663-5313/2020.2.56

\title{
Руслан Комісарчук,
}

канд. юрид. наук, дочент,

доцент кафедри криміналістики

Начіонального університету «Одеська юридична академія»

\section{ДІЯЛЬНІСТЬ ІЗ ВИЯВЛЕННЯ, РОЗСЛІДУВАННЯ ТА ПОПЕРЕДЖЕННЯ ЗЛОЧИНІВ ЯК ОБ'ЄКТ КРИМІНАЛІСТИЧНОЇ ТЕХНОЛОГІЇ}

У статті зазначені окремі складники вчення про криміналістичну технологію, на основі якого можливо виробити комплекс науково обгрунтованих практичних рекомендачій щодо підвищення ефективності забезпечення діяльності з виявлення, розслідування та попередження злочинів у сфері кримінального провадження.

Діяльність правоохоронних органів усіх без винятку держав здійснюється у формі застосування, дотримання, виконання і використання ними права для боротьби зі злочинністю. Але для ефективної реалізаиії їхіх завдань необхідна певна система, своєрідний звід засобів, правил, приниипів, прийомів, способів і методів, механізмів, які об'єднуються в одному системному утворенні. Таким системним утворенням, сформованим у прочесі накопичення криміналістичних знань, криміналістичних засобів і їх наростаючого використання в практичі боротьби зі злочинністю, повинна стати криміналістична технологія, під якою ми розуміємо сучасну криміналістику як технологію, яка формує криміналістичні засоби, забезпечуючи цим предметну сферу боротьби зі злочинністю. Тобто криміналістика - технологія боротьби зі злочинністю. Для зручності позначимо ї̈ терміном «криміналістична технологія». При иьому закономірні тендениї розвитку різних наук (природничих, гуманітарних, соціальних, когнітивних, різних технологій і т. п.) у різних крайнах світу, а на їх основі різних парадигм свідчать про інтеграцію різних галузей наукових знань у криміналістику, що вимагає багатоаспектного пізнання ї проблем у глобальних масштабах як иілісної теорії й практики. Саме в умовах інтеграчійних міжнародних процесів, пов'язаних із посиленням боротьби зі злочинністю, до вітчизняної криміналістики пред'являються нові вимоги, що зумовлюють: необхідність ї інтегращії в міжнародне криміналістичне співтовариство; об’єднання й координачію наукової криміналістичної роботи; гармонізачію методів виявлення й доказування злочинної діяльності на міжнародному рівні. Але для того, щоб иим вимогам відповідати, потрібно подолати методологічну кризу сучасної криміналістики, що можна здійснити за допомогою переходу до нової парадигми, або ї̈ мультипарадигмальності, здатної пояснювати проблеми, що виникають, $і$ визначати шляхи їх вирішення. Відповідно, потрібна оновлена гносеологія - це епістемологія криміналістики, як вчення про криміналістичне знання, $і$ ї̈ методологія, що зумовлює ї̈ технологічну природу як практики пізнання й форми раціональності чьього знання.

Ключові слова: загальна теорія криміналістики, вчення про криміналістичну технологію, технологічна парадигма, об’єкт криміналістики, завдання та функції криміналістики.

Постановка проблеми. Поняття об'єкта криміналістики - це основа, база, на якій виникла криміналістика. Та реальність, яку сформував дослідник-криміналіст у своїй пізнавальній діяльності, в принципі, була окреслена 3 моменту зародження криміналістичної науки і відбивалася у формульованих визначеннях. Вже саме визначення криміналістики як науки про розкриття і розслідування злочинів пов'язано з визначенням цілком певної об'єктивної сфери. Але криміналістика складається із самостійних компонентів різного знання, внаслідок чого вона займає особливе місце в науковому світовому ландшафті: на стику різних наук вона технологізує їх знання та власні з метою їх формування та подальшої реалізації як засобів діяльності $з$ виявлення, розслідування та попередження злочинів.

В умовах глобалізації українська модель криміналістики має багато перспектив, що дає підставу для відстоювання іiі як самостійної комплексної науки та практики, що займається розробкою прийомів, методів й засобів розкриття, розслідування та попередження злочинів. Тому саме 3 цих позицій необхідно переглянути історію вітчизняної криміналістики в аспекті їі зближення зі світовим баченням криміналістичних зв'язків з німецькою криміналістикою кінця XIX - 
початку XX століття, що дасть можливість розробити нову концепцію, нове визначення криміналістики як технології боротьби зі злочинністю (криміналістичної технології) 3 подальшим іiі визначенням як науки, навчальної дисципліни, практики.

Суть проблеми нині полягає не стільки в необхідності окреслення якогось нового кола цих реалій, скільки в дослідженні їх із наукових позицій, формуванні комплексу теоретичних положень щодо об'єкта криміналістики в «оновленому аспекті», як технології боротьби зі злочинністю (криміналістичної технології).

Аналіз останніх досліджень і публікацій. Об'єкт науки є первинним стосовно її предмета, системи, методів, принципів й інших категорій. Наявність певного об'єкта дослідження є онтологічною підставою існування окремої науки, іiї відокремлення від інших галузей знання.

Тому думки 3 приводу окремих питань, пов'язаних із поняттям та змістом об'єкта криміналістики, висловлювалися Р. С. Бєлкіним, І. А. Возгріним, В. В. Клочковим, В. Я. Колдіним, В. І. Корноуховим, Л. Д. Самигіною, М. П. Яболоковим s деякими іншими вченими. Склалися навіть певні підходи, які поєднують споріднені думки щодо кола реалій об'єктивної дійсності, що вивчаються криміналістикою.

Однак дискусії в цьому напрямі велися слабко, адже авторами висловлювались власні точки зору. Крім цього, сформовані теоретичні положення про об'єкт дослідження обмежуються перерахуванням і в кращому випадку короткою характеристикою явищ і процесів об'єктивної реальності, що входять у коло інтересів науки. Комплексного дослідження проблем об'єкта криміналістики, що включало би поняття, зміст, структуру, взаємозв'язок і співвідношення з іншими категоріями, не проводилося.

Тому основна мета статті полягає у визначенні поняття об'єкта дослідження в криміналістичній технології з подальшим її визначенням як науки, навчальної дисципліни, практики боротьби зі злочинністю в в тому числі у міжнародному масштабі.

Розглядаючи проблем, пов'язані з об'єктом і предметом криміналістики, вважаємо, слід використовувати «миследіяльнісний підхід», який у межах епістемології дає можливість говорити про криміналістику в новому ракурсі - як про технологію боротьби зі злочинністю - криміналістичну технологію (далі - КТ).

Річ у тому, що головним джерелом формування криміналістики як науки XIX сто- ліття була техніка, «ідея техніки». Але подальше ускладнення складових елементів техніки в XX-XXI століттях призвело до виникнення у XX столітті технологічної парадигми, яка сьогодні, в XXI сторіччі, набуває статус науково-практичного застосування, що в сукупності формує моделі різних наукових парадигм (техніко-економічна; організаційно-управлінська; інформаційнотехнологічна; аналітична; антропологічна; інтелектуальна і т. п.).

У правозастосуванні однією з таких парадигм $€$ інформаційно-технологічна парадигма криміналістики, що вимагає їі виділення у відносно самостійну сферу знань, предметом якої є системна взаємодія нового різновиду явищ - криміналістичних засобів (політичних, стратегічних, організаційноуправлінських, технічних, тактичних, методичних) боротьби зі злочинністю, склад та взаємодія яких і є, власне, змістом і формою криміналістичної технології.

Слід визнати незворотнім процес становлення нової криміналістичної парадигми, глибоких концептуальних змін у змісті криміналістики як технології боротьби зі злочинністю, що призведе до оновлення змісту основних наукових категорій, мети і цінностей міжнародного криміналістичного наукового співтовариства.

Інтерес до проблеми зумовлений об'єктивними причинами, такими як розвиток кримінальної процесуальної пошуково-пізнавальної діяльності осіб й органів, уповноважених на ії̈ здійснення, що вимагає більш розвинених форм криміналістичного забезпечення, i кількісне зростання технічних, тактичних, методичних засобів, що $\epsilon$ наслідком якісного розвитку діяльності правоохоронних органів і, відповідно, відображенням зростаючої соціальної потреби в більш детальній розробці прикладних питань здійснення різних її видів.

Наприклад, якщо на етапі оформлення криміналістики вона виступала як «кримінальна техніка», «мистецтво розслідування», то на сучасному етапі вчені включають до iii складу поряд із технікою максимально широкий інструментальний набір теоретичних, тактичних, психологічних, методичних, стратегічних, філософських, логічних й інших елементів, які все менше і менше належать тільки до криміналістичної діяльності, як це було у період зародження криміналістики в XIX столітті. Таке значне розширення обсягу змісту криміналістики зумовлено посиленням сьогодні інтересу вчених до дослідження проблем діяльності з виявлення, розслідування та попередження злочинів, що проявляється в поглибленій 
розробці ними загальної теорії та методології криміналістики, об'єкта і предмета криміналістичної науки, її суб'єктного складу, змісту, форми, видів.

На цій підставі в криміналістиці як науці орієнтація повинна бути на створення впорядкованої системи знань, засобів, способів, прийомів кримінальної процесуальної діяльності правоохоронних органів для досягнення правової мети та вирішення завдань у конкретних правових ситуаціях під час здійснення юридично значимих дій у боротьбі зі злочинністю.

Найбільш наочним результатом цього процесу є кількісне збільшення структурних елементів криміналістичної техніки, тактики і методики, що об'єктивно породжує потребу в їх ефективному системному використанні, без якого в умовах ускладнення соціальних відносин суб'єкти доказування не зможуть належним чином здійснювати свої інтереси, визначати і реалізовувати свою правову мету в боротьбі зі злочинністю. Прямим наслідком цього процесу логічного розвитку технологізації криміналістики є науковий інтерес до криміналістичної технології як до утворення, здатного консолідувати на системній основі розрізнені знання в «криміналістичні» - про засоби, правила, прийоми, способи, методи ефективної кримінальної процесуальної пошуково-пізнавальної діяльності правоохоронних органів.

Таким чином, грунтуючись на викладеному аналізі особливостей наукового дослідження різних аспектів діяльності з виявлення, розслідування та попередження злочинів, можна зробити висновок про те, що iï розвиток пов'язаний з ускладненням суспільного життя, яке вимагає більш розвинутої форми її криміналістичного забезпечення, логічно призводить до виникнення криміналістичної технології. Причому вважаємо, що ті уявлення, які склалися в науковій літературі про співвідношення криміналістичної техніки, тактики і методики як родових утворень, вивчають і забезпечують своїм інструментарієм лише слідознавчий аспект, не є переконливими, адже не відповідають сучасним потребам криміналістичної теорії й практики. Зрозуміло, їх розмежування в рамках діяльності з виявлення, розслідування та попередження злочинів обгрунтоване й необхідне, але це розмежування існує як їх діалектична взаємозалежність, взаємопроникнення.

Потрібна концепція, що охоплює всю сферу боротьби зі злочинністю. 3 цих позицій головне в криміналістиці - це те, що безпосередньо затребуване і використовується практикою, тобто криміналістичні знання, методи, прийоми й засоби. При цьому має йтися не тільки про їх розробку, але й про забезпечення їх впровадження у практичну діяльність правоохоронних органів. Теоретичні криміналістичні знання повинні розглядатися не як основа, а як засіб забезпечення подальшого вирішення прикладних проблем практики. Адже криміналістичне знання забезпечує розробку та вдосконалення криміналістичного арсеналу засобів боротьби зі злочинністю. Тільки за такої умови предметно-технологічної орієнтації криміналістика може стати джерелом ефективних змін у практиці виявлення, розслідування і попередження злочинів. Для цього потрібне технологічне вирішення практичних криміналістичних завдань, що виникають у повсякденній криміналістичній діяльності. Тому криміналістичні знання через методи, прийоми і засоби набувають статусу фундаментального знання, безпосереднє використання якого здатне цілеспрямовано змінювати зміст практичної діяльності з виявлення, розслідування та попередження злочинів.

Окремі засоби, правила, способи і прийоми діяльності з виявлення, розслідування та попередження злочинів вивчаються в рамках галузевої процесуальної науки - кримінального процесу, проте ним охоплюється тільки юрисдикційний спосібздійснення правозастосовної діяльності. Крім того, в рамках кримінальної процесуальної науки сконцентровані тільки ті інструментальні складники технології застосування права в тому числі судами, що нормативно регламентовані, а це значно обмежує технологічний інструментарій діяльності з виявлення, розслідування та попередження злочинів. На наше переконання, саме за допомогою концепції КТ можна звести воєдино натепер фрагментарні i роз'єднані науково-практичні концепції, присвячені окремим питанням діяльності 3 виявлення, розслідування та попередження злочинів (в тому числі і концепції криміналістичної стратегії, криміналістичної політики, криміналістичної безпеки).

Розглянувши питання про становлення концепції криміналістичної технології, звернемося до питання про її місце в системі юридичного знання, співвідношення 3 наукою права та іншими науками, а також встановимо її об'єкт, предмет, мету, завдання та співвідношення з юридичною діяльністю.

Криміналістичну технологію не можна зводити тільки до практики або тільки до науки. Виходячи із сутності загального визначення технології, до її сфери має належати як використання, так і саме формування науково-технологічних знань. Відповідно, якщо юридична наука дає узагальнені, принципові знання про боротьбу зі злочинністю (норми 
належного й дозволеного і реакція на протиправну поведінку в процесі виявлення, розслідування та попередження злочинів), то криміналістична технологія включає в себе знання про те, яким чином і за допомогою яких криміналістичних засобів слід здійснювати діяльність із боротьби зі злочинністю, що може служити підставою для вироблення криміналістичною наукою нових знань

Тому в силу своєї специфіки криміналістична технологія є спеціальною прикладною юридичною наукою, яка пристосовуе для своєї мети дані інших наук для боротьби зі злочинністю, що застосовуються не безпосередньо, а тільки після їх перетворення в специфічне криміналістичне знання, на підставі якого можливо точно встановити, які конкретно криміналістичні засоби необхідно використовувати в реальній діяльності з виявлення, розслідування та попередження злочинів 3 метою досягнення бажаного результату. Сукупність технологічних знань такого роду і заснованих на них технічних, тактичних, методичних, стратегічних, політичних засобів, засобів криміналістичної безпеки й становить зміст криміналістичної технології як прикладної юридичної науки.

Звісно ж, сутнісний характер криміналістичної технології полягає у тому, що вона насамперед $є$ системним утворенням, а тому має складний, об'ємний склад. У зв'язку з цим вона повинна розглядатися в двох аспектах у зовнішньому - по відношенню до об'єкта, який іï впорядковує і перетворює, і внутрішньому - по відношенню до складових частин і механізму самої криміналістичної технології як системи. Відповідно, залежно від того, в якому аспекті вона виступає, змінюється і їі початок. Так, стосовно об'єкта, який її впорядковує і перетворює за допомогою її структурних елементів суспільних відносин (у зовнішній сфері), вона являє собою сукупність (систему) криміналістично-технологічних засобів діяльності з виявлення, розслідування та попередження злочинів, в ході якої перетворюються відповідні суспільні відносини для боротьби зі злочинністю.

Тобто в цьому сенсі криміналістика є технологією, яка визначає, що саме необхідно зробити для того, щоб досягти поставленої правової мети в боротьбі зі злочинністю, яким чином необхідно здійснювати ту чи іншу активно перетворюючу діяльність із виявлення, розслідування та попередження злочинів. У цьому своєму аспекті вона статична i, відповідно, не тотожна діяльності з виявлення, розслідування та попередження злочинів в цілому або якоїсь іï сторони, частини, зрозуміло, як система цілеспрямованих дій і операцій, спрямованих на вирі- шення криміналістичного завдання; спосіб забезпечення правових основ у суспільстві; вид більш загальної людської діяльності, яка часто визначається як спосіб існування людини, як система матеріально-практичних, інтелектуальних і духовних операцій.

Вважаємо, що криміналістична технологія у своєму прикладному значенні є одним із «діяльнісних елементів» діяльності з виявлення, розслідування та попередження злочинів як юридичної діяльності. Вона фактично створена для здійснення діяльності з виявлення, розслідування та попередження злочинів своїми криміналістично-технологічними засобами.

Якщо ж розглядати криміналістичну технологію у внутрішньому аспекті, то вона набуває діяльнісного начала, проявляється у формуванні криміналістично-технологічних засобів здійснення діяльності з виявлення, розслідування та попередження злочинів найбільш оптимальним чином, що сприяють досягненню бажаного для суб'єкта цієї діяльності правового результату в процесуальні терміни і 3 мінімальними матеріальними, часовими і правовими витратами. Відповідно, виходячи з такого розуміння характеру криміналістичної технології, в цьому своєму аспекті вона також не тотожна діяльності 3 виявлення, розслідування та попередження злочинів та іï окремим складникам, оскільки спрямована на отримання криміналістично-технологічного знання про способи здійснення діяльності 3 виявлення, розслідування та попередження злочинів.

Беручи до уваги епістемологічний характер криміналістичної технології та її аналітичну парадигму, зазначимо, що одним з основних складників її діяльнісного начала $€$ інтелектуально-вольова діяльність зі створення нових і вдосконалення вже наявних прийомів, правил, способів, методів, складників її структури в тому числі шляхом дослідження даних (через криміналістичний моніторинг) про результати застосування цих правил і методів діяльності з виявлення, розслідування та попередження злочинів, а також пристосування їх до нагальних потреб активно-перетворювального епістемологічного знання криміналістичної технології як науки.

Саме завдяки цьому діяльнісному характеру внутрішнього аспекту, криміналістична технологія є не просто сукупністю різних структурних елементів, а системою, що саморозвивається. Ця особливість криміналістичної технології дозволяє визначити iii як автономну систему, яка, рухаючись з власною динамікою через внутрішні зміни, іманентно розвивається на власній основі - 
знаннях про засоби діяльності з виявлення, розслідування та попередження злочинів. Відповідно, цей дуалістичний характер криміналістичної технології має визначальний вплив на її внутрішній зміст, відбивається на іï̈ об’єкті і предметі.

Так, якщо у своєму науковому (пізнавальному) аспекті криміналістична технологія як наука спрямована на з'ясування суті явищ навколишнього світу, що потрапляють у сферу її впливу, опис їх структури, визначення їх функцій, пояснення причин і механізму їх виникнення та подальшого розвитку, то у своєму практичному (прикладному) аспекті вона спрямована на впорядковане, системне застосування наукових знань у реальній діяльності з виявлення, розслідування та попередження злочинів.

Відповідно, такий дуалізм позначається на характері впливу криміналістичної технології на об'єкт. Таквона впливає на об'єкт його практичного перетворення, 3 одного боку, з метою діяльності з виявлення, розслідування та попередження злочинів, а $з$ іншого - з метою його пізнання для подальшого вдосконалення діяльності правоохоронних органів.

Тому предметом впливу криміналістичної технології як у пізнавальному, так і в перетворювальному сенсі виступає діяльність 3 виявлення, розслідування та попередження злочинів. Криміналістична технологія виступає тут як засіб оптимізуючого перетворення криміналістично-правової дійсності. Цей дуалістичний характер криміналістичної технології визначає її мету й завдання. Метою криміналістичної технології повинно бути, з одного боку, забезпечення суб'єктів діяльності 3 виявлення, розслідування та попередження злочинів відповідними криміналістично-технологічними засобами боротьби зі злочинністю, а з іншого - отримання знання про сутність засобів, прийомів, методів і правил створення та їх реалізація в діяльності 3 виявлення, розслідування та попередження злочинів; пристосування даних різних наук для боротьби зі злочинністю; розробка на цій базі правил поведінки, стандартних алгоритмів, шаблонів поведінки суб'єктів діяльності правоохоронних органів з метою досягнення ними оптимального бажаного правового результату; систематизація діяльності правоохоронних органів і вироблення засобів її здійснення в рамках цих шаблонів, розробка інструкцій, рекомендацій, методик та інших зовнішніх форм вираження криміналістично-технологічного знання щодо здійснення різних видів діяльності з виявлення, розслідування та попередження злочинів і т. д.

Специфіка об'єкта криміналістичної технології проявляється у тому, що метою, з епістемологічної позиції, є вивчення практики застосування її інструментарію в діяльності прокурора, слідчого, працівника оперативного підрозділу, спеціаліста, експерта, слідчого судді з виявлення, розслідування та попередження злочинів 3 точки зору його ефективності та подальшого вдосконалення.

Отже, КТ має своїм об'єктом криміналістичне пізнання діяльності з виявлення, розслідування та попередження злочинів як специфічної логіко-методологічної процедури. Завдяки своїй властивості, КТ має право називатися самодостатньою, «автономною» науковою системою, а не прикладною, синтетичною і т. п.

\section{Висновки}

Таким чином, сутність КТ полягає в єдності і взаємодії пізнавального, перетворювального і впорядковуючого впливу суб'єкта на суспільні відносини, що підлягають перетворенню і складаються з приводу формування та реалізації криміналістичних засобів у боротьбі зі злочинністю.

У КТ здійснюється опанування і пристосування знань різних наук до конкретної мети - створення і використання технічних, тактичних, методичних, стратегічних, політичних засобів, засобів криміналістичної безпеки для розробки на цій основі алгоритмів поведінки суб'єктів діяльності з виявлення, розслідування та попередження злочинів з метою отримання ними ефективних криміналістичних засобів для боротьби зі злочинністю.

Резюмуючи вищевикладене, можна сформулювати таке визначення криміналістичної технології: це науково обгрунтована система засобів (техніка), способів і методів (тактика, методика), принципів, планів і прогнозів (стратегія) у практичній діяльності компетентних суб'єктів й учасників, спрямована на виявлення, розслідування та попередження злочинів та інших явищ, що їх породжують. 
The article identifies some components of the doctrine of forensic technology, on the basis of which it is possible to develop a set of scientifically substantiated practical recommendations for improving the effectiveness of ensuring activities in the detection, investigation and prevention of criminal offenses.

The activities of law enforcement agencies of all states, without exception, are carried out in the form of application, observance, enforcement and use of their right to fight crime. But for the effective realization of their tasks, a certain system, a peculiar set of tools, rules, principles, techniques, methods and methods, mechanisms that unite in one systemic formation, is needed. Such a systemic formation, formed in the process of accumulation of forensic knowledge, forensic means and their increasing use in the practice of combating crime, should become the forensic technology, by which we understand modern forensics, as a technology that shapes forensic means, preventing the crime. That is, forensics is a technology to fight crime. For convenience, let's call it "forensic technology." The natural tendencies of development of different sciences (natural sciences, humanities, social, cognitive, different technologies, etc.) in different countries of the world, and on the basis of different paradigms, testify to the integration of different branches of scientific knowledge in criminalistics, which requires multidimensional cognition. its problems globally, as a coherent theory and practice. It is in the context of international integration processes related to the intensification of the fight against crime that new requirements are imposed on domestic forensics, which stipulates: the need for its integration into the international forensic community; integration and coordination of scientific forensic work; harmonization of methods for detecting and proving criminal activity at the international level. But in order to meet these requirements, we need to overcome the methodological crisis of modern forensics, which can be accomplished through the transition to a new paradigm, or its multiparadigmality, capable of explaining emerging problems and determining ways to solve them. Accordingly, an updated epistemology is needed - this is the epistemology of forensics, as the doctrine of forensic knowledge, and its methodology, which determines its technological nature, as the practices of cognition and the forms of rationality of that knowledge.

Key words: general forensics theory, doctrine of forensic technology, technological paradigm, object of forensics, tasks and functions of forensic science. 